\title{
Customers Loyalty Through Experiential Marketing on The Salon Crisni in Singaraja
}

\author{
Ni Luh Nurkariani1*, Gusti Putu Eka Kusuma²
}

1,2 Sekolah Tinggi Ilmu Ekonomi Satya Dharma, Indonesia

\section{ART ICLE IN F O}

Article history:

Received March 19, 2021

Revised April 03, 2021

Accepted May 01, 202

Available online May 25, 2021

Keywords:

Experiential Marketing;

Customers Loyalty

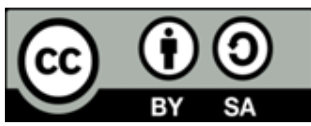

This is an open access article under the CC BY-SA license.

Copyright $\left({ }_{0} 2021\right.$ by Author. Published bv Universitas Pendidikan Ganesha.

\begin{abstract}
A B S T R A C T
Business development is currently growing rapidly, one of which is a business engaged in services. In running a beauty salon service business, it is very important to make customers loyal or what is called Customer Loyalty. Customer loyalty is customer commitment to a store brand or supplier based on a very positive attitude in long-term purchases, it is easier to develop and succeed if the company can make customers loyal. The purpose of this study was to determine sense, feel, think, act, relate to customer loyalty at Krisni salon. The analysis technique used in this research is validity and reliability test, multiple regression analysis, multiple correlation analysis, classical assumption test, determination test, t-test and hypothesis test with t-test. The results showed that experiential marketing which consists of sense, feel, think, act, relate has a positive and significant effect on customer loyalty at Krisni salon in Singaraja. These results are proven by testing the hypothesis with the $\mathrm{t}$-test which shows that $\mathrm{t}$-count $>\mathrm{t}$-table and the results of model testing with $\mathrm{t}$-test which show that $\mathrm{t}$-count $>\mathrm{t}$-table. This result means that in creating customer loyalty, Krisni salon must pay attention to the strategies used, one of which is experiential marketing.
\end{abstract}

\section{INTRODUCTION}

Business development is currently growing rapidly, one of which is a business engaged in services (Tjiptono, 2008; Usmara, 2008). In line with economic, technological and cultural developments in this modern era (Soliha et al., 2021; Wahyuningtyas et al., 2017; Widowati \& Tsabita, 2017). A rapidly growing service business is a business engaged in salon and body care services, which includes hair, facial and body beauty treatments (Bisnarti, 2015; Ekasari, 2015). Beauty care has become a necessity that is considered important by some people, especially for women. Beauty salon as a service facility to improve appearance through make-up and skin and hair beauty treatments using manual, preparative and decorative cosmetics by beauticians according to their competence. In running a beauty salon service business, it is very important to make customers loyal or what is called Customer Loyalty because business competition is getting out of control (Lispentia \& Trijumansyah, 2017). Using customer loyalty as a step in running a business, it is easier to develop and succeed if the company can retain loyal customers (Tantowi \& Pratomo, 2020; Yustica, 2021).

In running a beauty salon service business, it is very important to make customers loyal or what is called Customer Loyalty because the competition in the service business is getting out of control (Jasfar, 2005; Kertajaya, 2010). The essence of Experiential Marketing is to give a memory or impression to customers through their services. So it can be concluded that experiential marketing is an approach in marketing that has actually been done since ancient times until now by marketers. This approach is considered very effective because in line with the times and technology, marketers place more emphasis on product differentiation to differentiate their products from competitor products (Hasan, 2009; Panjaitan, 2017). There are five dimensions of Experiential Marketing, namely: Sense, Feel, Think, Act, Relate (Andriani \& Fatimah, 2018; Oeyono, 2013). Sense is a type of experience that appears to create a sensory experience through the eyes, ears, skin, tongue and nose. Sense marketing is one way to touch consumer emotions through experiences that can be obtained by consumers through the five senses (eyes, ears, tongue, skin, and nose) (Rizal, 2016; Saraswati, 2013). Feel Marketing is a type of experience that appears to touch the deepest and emotional feelings of customers with the aim of creating an effective experience. Think Marketing to influence customers to engage in creative thinking and create awareness through thought processes that have an impact on the re-evaluation of the company, its products and 
services. Act Marketing is a type of experience that aims to influence behavior, lifestyle and interaction with consumers (Sasongko, 2011; Smilansky, 2017). Act is one way to shape consumer perceptions of the products and services concerned. Relate Marketing is a type of experience that is used to influence customers and combines all aspects, sense, feel, think, and act (Prasetyo \& Wasis, 2019; Wahyuningsih et al., 2021).

Sense is a method used by companies in applying a product or service through sense senses received by consumers so that consumers can buy a product or service offered by the company. Sense is a type of experience where the creation of experiences through the five senses, including sight, smell, taste, sound and touch (Putri, 2018; Schmitt \& Rogers, 2008). Sense experiences can be stimulated by providing excitement, pleasure and satisfaction to consumers. Sense deals with verbal and visual symbols such as interior design, room decoration and music that can create positive experiences for consumers Feel is a form of service provided by the company by touching consumer emotions such as hospitality, politeness and good attitude so that consumer comfort is created and will provide a positive experience. Feel is a small attention shown to consumers with the aim of touching the customer's emotions in an extraordinary way (Kertajaya, 2010; Yuliawan \& Ginting, 2016).

Think experience includes creative and cognitive, which means in marketing products and services, think requires intelligence which aims to create cognitive experiences and problem solving that involve consumers creatively. The principle of applying think, namely by creating a surprise to consumers visually, verbally and conceptually. Furthermore, it is added with a little intrigue as an attraction and finally by doing provocation to perfect it. Think is to encourage consumers to be interested and think creatively so that they may be able to produce a re-evaluation of the company and the brand (Andriani \& Fatimah, 2018; Oeyono, 2013). Relate is a type of experience that is used to influence customers and combines all aspects of sense, feel, think, and act and focuses on creating positive perceptions in the eyes of customers. Relate is a combination of four aspects of experiential marketing, namely sense, feel, think, and act (Putri, 2018; Schmitt \& Rogers, 2008; Smith \& Hanover, 2016). Relate is shown through relationships with other people, other groups (work and lifestyle) or a broader and abstract social community such as country, society and culture. The purpose of relate is to create a social identity experience by connecting consumers and the culture and social environment that the product or service reflects. From the description above, it is very important to build good relationships with customers so that they can always be loyal customers in the long term. As a reference for conducting research, the following graph of the data on the number of customers during the 2016-2019 period is as presented in Figure 1.

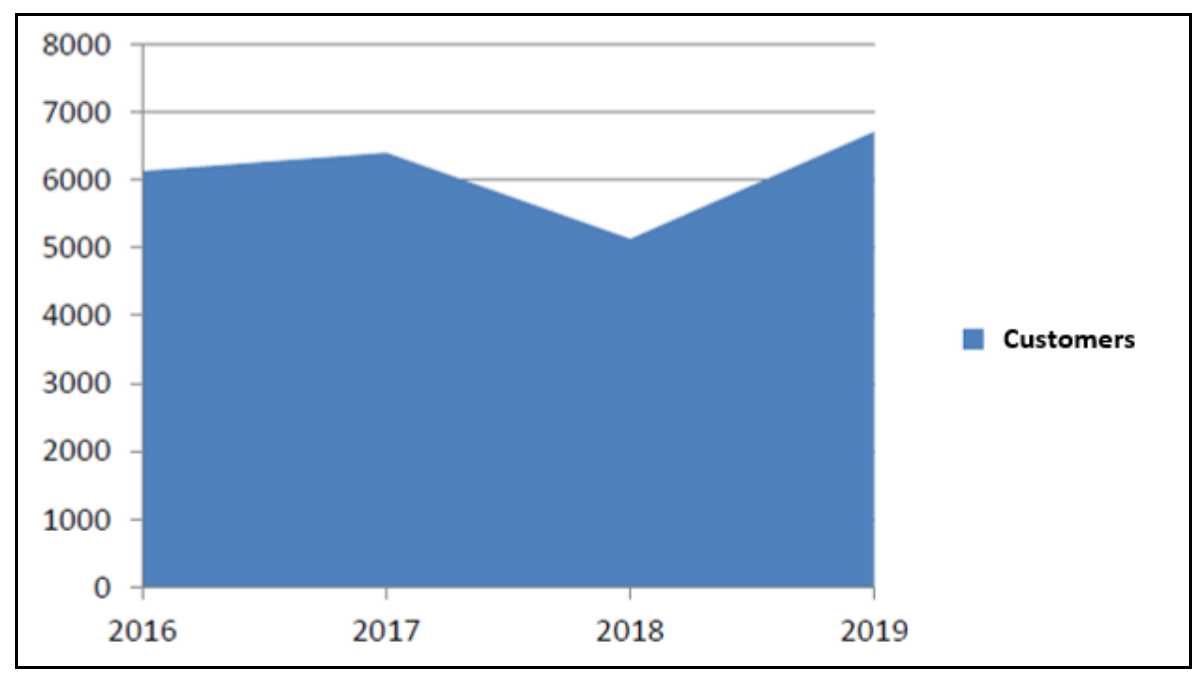

Figure 1. Consumers on Crisni Salon and Spa during 2016-2019 Period

Based on the data obtained from Crisni Salon and Spa (Solus Per Aqua) Singaraja which is shown in graph 1 above, it can be explained that in 2016 the number of customers reached 6130 and in 2017 there was an increase in the number of customers, which was above 6400 customers. In 2018 there was a decrease in the number of subscribers by 5130 and in 2019 there was an increase in the number of subscribers by 6710. When viewed in graphical form, the increase was not significant, which means that the trend of increase was not always up but decreased. The problem that occurs is the decrease in the number of customers in 2017. This is due to the salon's lack of attention to its customers in treating or serving its customers well and not touching the feelings of customers, other than those resulting from 
increasingly rapid business competition. Based on this background, to achieve the company's goals in order to create long-term relationships with customers, one strategy is needed to maintain relationships so that customers remain loyal customers in the long term and one of them is to use the Experiential Marketing strategy. It is hoped that this research can provide an overview of how experiential marketing strategies can form customer loyalty.

\section{METHODS}

The types of data used in this study include quantitative and qualitative data, while the data sources used in research are primary and secondary data (Ferdinand, 2006). The purpose of this study was to determine sense, feel, think, act, relate to customer loyalty at Krisni salon in Singaraja. The research design in this study are presented in Figure 2.

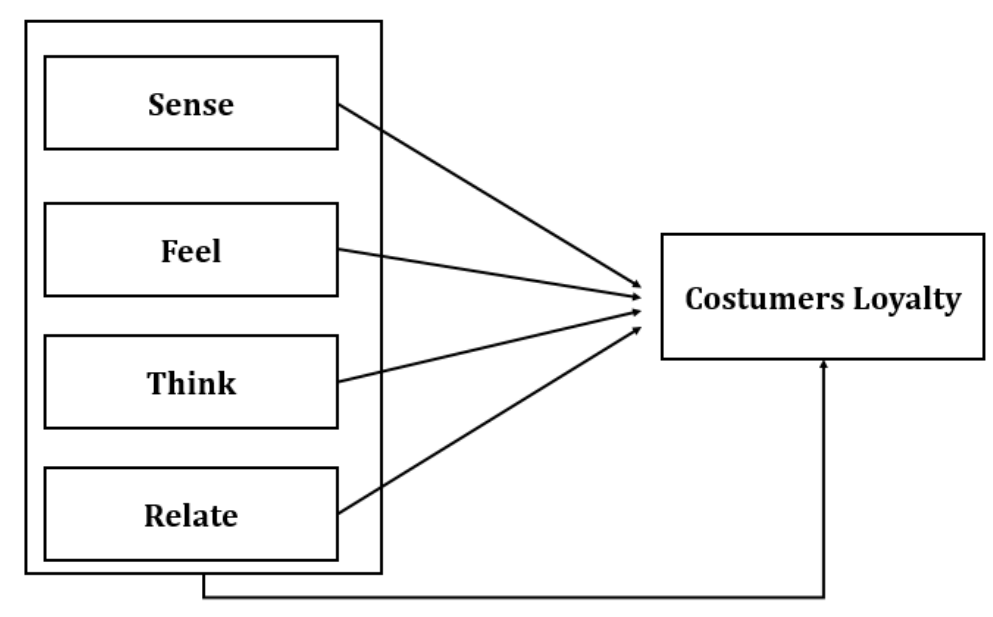

Figure 2. Research Framework

The population in this study were 90 customers at Krisni Salon in Singaraja. The data collection technique in this study is to use a questionnaire technique. The research and testing instruments in this study used the Validity and Reliability Test. The data analysis technique in this study uses Multiple Linear Regression Analysis, Multiple Correlation Analysis, Classical Assumption Test Analysis, Model Feasibility Test (Goodness of Fit), and T-Test Analysis (Ghozali, 2018; Santoso, 2019). Stages of data analysis namely: The first stage is to evaluate the measurement model (outer model). Test validity and reliability by performing Convergent Validity, Discriminant Validity Composite Reliability, Cronbach's Alpha and AVE. Formative indicators are tested with weight significance and multicolonrity. The second stage is to evaluate the structural model (inner model). The evaluation in this model will be seen from the coefficient of determination (R2), predictive relevance (Q2), goodness of git index (GoF). Hypothesis testing is seen from t-statistical values and probability values. Hypothesis testing uses statistical values.

\section{RESULTS AND DISCUSSIONS}

\section{Results}

The results of data analysis in this study are presented in Table 1.

Table 1. The Results of Data Analysis

\begin{tabular}{clccccc}
\hline No. & Variable & $\begin{array}{c}\text { Regression } \\
\text { Coefficient }\end{array}$ & $\begin{array}{c}\text { Determination } \\
\text { Coefficient }\end{array}$ & Correlation & t-count & t-table \\
\hline 1 & Sense & 0.177 & $28.1 \%$ & 0.588 & 2.680 & \\
2 & Feel & 0.070 & $14.9 \%$ & 0.502 & 1.779 & 1.663 \\
3 & Think & 0.265 & $30.4 \%$ & 0.542 & 2.297 & \\
4 & Relate & 0.055 & $8.5 \%$ & 0.400 & 1.783 & \\
\hline
\end{tabular}




\section{Discussion \\ The Influence of Sense on Customer Loyalty at Krisni Salon in Singaraja}

Based on the research results, it is found that Sense has a positive effect on Customer Loyalty at Krisni Salon in Singaraja with a regression coefficient of 0.177 and a determination coefficient of $28.1 \%$ with a correlation result of 0.588 which means that there is a moderate correlation between the independent variable Sense and the dependent variable. Customer loyalty. Then the results of hypothesis testing with the T-test showed that the value of $t$-count $>t$-table $(2,680>1,663)$ so that the hypothesis is accepted. This result is supported by the theory presented by several studies that stated sense is a type of experience where the creation of experiences through the five senses, including sight, smell, taste, sound and touch (Iisnawati et al., 2020; Katrine, D., \& Harini, 2018; Rianti \& Oetomo, 2017; Rozaqie \& Kusumawati, 2016).

\section{The Influence of Feel on Customer Loyalty at Krisni Salon in Singaraja}

Based on the research results, it is found that Feel has a positive effect on Customer Loyalty at Krisni Salon in Singaraja with a regression coefficient of 0.070 and a determination coefficient of $14.9 \%$ with a correlation result of 0.502 which means that there is a moderate proportional relationship between the independent variable Feel and the variable. tied to Customer Loyalty. Then the results of hypothesis testing with the T-test showed that the value of $\mathrm{t}$-count $>\mathrm{t}$-table $(1.779>1.663)$ so that the hypothesis is accepted. This result is supported by the theory presented in previous studies that feel is a small concern shown to consumers with the aim of touching the customer's emotions in an extraordinary way (Akbar, 2017; Devindiani \& Wibowo, 2016; Febrini et al., 2019; Jatmiko \& Andharini, 2012).

\section{The Influence of Think on Customer Loyalty at Krisni Salon in Singaraja}

Based on the results of the study, it was found that Think had a positive effect on Customer Loyalty at Krisni Salon in Singaraja with a regression coefficient of 0.265 and a determination coefficient of $30.4 \%$ with a correlation result of 0.542 , which means that there is a moderate correlation between Think's independent variables and the variable. tied to Customer Loyalty. Then the results of hypothesis testing with the T-test showed that the value of $t$-count $>t$-table (2.297> 1.663) so that the hypothesis is accepted. This result is supported by the theory presented in previous studies (Chang, 2021; Kertajaya, 2010; Mukiira et al., 2017; Skandalis et al., 2019). Think (way of thinking) is one of the ways companies do to bring commodities into experience by continuously customizing.

\section{The Influence of Relate on Customer Loyalty at Krisni Salon in Singaraja}

Based on the research results, it is found that Realte has a positive effect on Customer Loyalty at Krisni Salon in Singaraja with a regression coefficient of 0.055 and a determination coefficient of $8.5 \%$ with a correlation result of 0.400 which means that there is a moderate correlation between independent variables. with the dependent variable Customer Loyalty. Then the results of hypothesis testing with the T-test showed that the value of $\mathrm{t}$-count $>\mathrm{t}$-table $(1.783>1.663)$ so that the hypothesis is accepted. This result is supported by several previous study (Ihtiyar et al., 2019; Österle et al., 2018; Wiedmann et al., 2018; Yuliawan \& Ginting, 2016). Relate is a type of experience used to influence customers and combines all aspects of sense, feel, think, and act and focuses on creating positive perceptions in the eyes of customers.

\section{CONCLUSION}

From several existing indicators in the experimental marketing dimension approach, think indicators have a significant and dominant influence in forming a strong emotional bond with customers so as to form customer loyalty.

\section{REFERENCES}

Akbar, D. A. (2017). Pengujian Relevansi Experiential Marketing Dan Loyalitas Konsumen. I-ECONOMICS: A Research Journal on Islamic Economics, 3(1), 93-114. http://jurnal.radenfatah.ac.id/index.php/ieconomics/article/view/1466.

Andriani, R., \& Fatimah, R. (2018). Strategi Experiential Marketing Sebagai Metode Pendekatan Dalam Meningkatkan Revisit Intention Wisatawan Sabda Alam Garut. Jurnal Kajian Ilmiah, 18(3), 206214. https://doi.org/10.31599/jki.v18i3.287.

Bisnarti, A. (2015). Pengaruh Experiential Marketing Terhadap Loyalitas Pelanggan Pada The Family Spa. Jurnal 
https://seminar.bsi.ac.id/knist/index.php/UnivBSI/article/view/77.

Chang, W.-J. (2021). Experiential marketing, brand image and brand loyalty: a case study of Starbucks. British Food Journal, 123(1), 209-223. https://doi.org/https://doi.org/10.1108/BFJ-01-20200014.

Devindiani, E., \& Wibowo, L. A. (2016). Pengaruh experiential marketing terhadap customer satisfaction serta dampaknya pada customer loyalty (survei pada pengguna smartphone di komunitas online apple dan samsung regional bandung). Journal of Business Management Education (JBME), 1(1), 149-159. https://ejournal.upi.edu/index.php/JBME/article/view/2284.

Ekasari, N. (2015). Pengaruh Experiential Marketing terhadap loyalitas pelanggan klinik perawatan kulit natasha kota Jambi. Jurnal Penelitian Universitas Jambi: Seri Humaniora, 17(2).

Febrini, I. Y., Widowati, R., \& Anwar, M. (2019). Pengaruh Experiential Marketing Terhadap Kepuasan Konsumen Dan Minat Beli Ulang Di Warung Kopi Klotok, Kaliurang, Yogyakarta. Jurnal Manajemen Bisnis, 10(1), 35-54. http://journal.umy.ac.id/index.php/mb/article/view/6130.

Ferdinand, A. (2006). Metode Penelitian Manajemen. Universitas Diponegoro.

Ghozali, I. (2018). Aplikasi Analisis Multivariate dengan Program IBM SPSS 25 (9th editio). Badan Penerbit Universitas Diponegoro.

Hasan, A. (2009). Marketing. Medpress.

Ihtiyar, A., Barut, M., \& Ihtiyar, H. G. (2019). Experiential marketing, social judgements, and customer shopping experience in emerging markets. Asia Pacific Journal of Marketing and Logistics, 31(2), 499-515. https://doi.org/10.1108/APJML-02-2018-0081.

Iisnawati, I., Nofiawaty, N., \& Nazaruddin, A. (2020). Consumer Loyalty of Shopee's User in South Sumatera through Experiential Marketing. Sriwijaya International Journal Of Dynamic Economics and Business, 3(4), 301-314. http://sijdeb.unsri.ac.id/index.php/SIJDEB/article/view/172.

Jasfar, F. (2005). Manajemen Jasa: Pendekatan Terpadu. Ghalia Indonesia.

Jatmiko, R. D., \& Andharini, S. N. (2012). Analisis experiential marketing dan loyalitas pelanggan jasa wisata (Studi pada Taman Rekreasi Sengkaling Malang). Jurnal Manajemen Dan Kewirausahaan, 14(2), 128-137. https://doi.org/10.9744/jmk.14.2.128-137.

Katrine, D., \& Harini, C. (2018). The analysis of effect of sense, feel, think, act, and relate as the experiential marketing variables to customer loyalty of Andelir Hotel Semarang. Journal of Management, 4(4). http://jurnal.unpand.ac.id/index.php/MS/article/view/919/0.

Kertajaya, H. (2010). Connect! Surfingnew Wave Marketing. Gramedia Pustaka Utama.

Lispentia, E., \& Trijumansyah, A. (2017). Pengaruh Experiential Marketing Terhadap Loyalitas Pelanggan Pada Bridal \& Salon Di Cimareme. Konferensi Nasional Ilmu Sosial Dan Teknologi, 1(1). http://seminar.bsi.ac.id/knist/index.php/UnivBSI/article/view/77.

Mukiira, E. M., Musau, M. C., \& Munyao, M. J. (2017). Effect of experiential marketing in building brand equity: A case of selected Unilever Tanzania brands. International Journal of Supply Chain Management, 2(1), 1-31. https://www.iprjb.org/journals/index.php/IJSCM/article/view/376.

Oeyono, J. T. (2013). Analisa pengaruh experiential marketing terhadap loyalitas konsumen melalui kepuasan sebagai intervening variabel di tator cafe surabaya town square. Jurnal Strategi Pemasaran, 1(2), 1-9. http://publication.petra.ac.id/index.php/manajemenpemasaran/article/view/959.

Österle, B., Kuhn, M. M., \& Henseler, J. (2018). Brand worlds: Introducing experiential marketing to B2B branding. Industrial Marketing Management, 72, 71-98. https://doi.org/10.1016/j.indmarman.2018.04.015.

Panjaitan, D. F. (2017). Pengaruh Experiential Marketing terhadap Loyalitas Konsumen yang Dimediasi Variabel Kepuasan Konsumen (Studi Kasus: Fitness First Cabang Oakwood). Media Manajemen Jasa, 4(1). https://doi.org/10.52447/mmj.v4i1.711.

Prasetyo, D. W., \& Wasis, W. (2019). Pengaruh Experiental Marketing terhadap loyalitas konsumen dan dimediasi oleh kepuasan konsumen. MBR (Management and Business Review), 3(2), 71-82. https://doi.org/10.21067/mbr.v3i2.4616.

Putri, D. P. (2018). Pengaruh Experiential Marketing Terhadap Kepuasan Dan Loyalitas Konsumen Pada Pembelian Sayuran Organik Di Loka Malang. Universitas Brawijaya.

Rianti, O., \& Oetomo, H. W. (2017). Pengaruh Experiential Marketing Terhadap Loyalitas Konsumen dengan Kepuasan Konsumen Sebagai Variabel Intervening. Jurnal Ilmu Dan Riset Manajemen (JIRM), 6(8). http://jurnalmahasiswa.stiesia.ac.id/index.php/jirm/article/view/1899.

Rizal, M. (2016). Pengaruh Experiential Marketing terhadap Loyalitas Pelanggan Kolam Renang Mutiara Waterpark Perumnas Langsa. Jurnal Manajemen Dan Keuangan, 5(1), 469-478. https://ejurnalunsam.id/index.php/jmk/article/view/48.

Rozaqie, S. M., \& Kusumawati, A. (2016). Analisis Faktor-faktor Experiential Marketing Dan Pengaruhnya 
Terhadap Loyalitas Pelanggan (Survei Pada Pelanggan Legend Coffee Malang). Jurnal Administrasi Bisnis, $\quad 38(1)$, 30-39. http://administrasibisnis.studentjournal.ub.ac.id/index.php/jab/article/view/1478.

Santoso, S. (2019). Menguasai SPSS Versi 25. Elex Media Komputindo.

Saraswati, R. (2013). Pengaruh Experiential Marketing terhadap Loyalitas (Studi Pada Pelanggan Taman Indie Resto Malang). Jurnal Administrasi Bisnis, 6(1). http://administrasibisnis.studentjournal.ub.ac.id/index.php/jab/article/view/270.

Sasongko, I. A. (2011). Pengaruh Experiential Marketing dan Promosi Terhadap oyalitas Pelanggan Pada Objek Wisata Umbul Sidomukti Kabupaten Semarang. Universitas Negeri Semarang.

Schmitt, B. H., \& Rogers, D. L. (2008). Handbook on Brand and Experience Management. Edward Elgar Publishing.

Skandalis, A., Byrom, J., \& Banister, E. (2019). Experiential marketing and the changing nature of extraordinary experiences in post-postmodern consumer culture. Journal of Business Research, 97, 43-50. https://doi.org/10.1016/j.jbusres.2018.12.056.

Smilansky, S. (2017). Experiential marketing: A practical guide to interactive brand experiences. Kogan Page Publishers.

Smith, K., \& Hanover, D. (2016). Experiential marketing: Secrets, strategies, and success stories from the World's greatest brands. John Wiley \& Sons.

Soliha, E., Aquinia, A., Hayuningtias, K. A., \& Ramadhan, K. R. (2021). The Influence of Experiential Marketing and Location on Customer Loyalty. The Journal of Asian Finance, Economics and Business, 8(3), 1327-1338. https://doi.org/10.13106/jafeb.2021.vol8.no3.1327.

Tantowi, A. I., \& Pratomo, A. W. (2020). Pengaruh Store Atmosphere dan Experiential Marketing Terhadap Keputusan Pembelian Di Kopi Daong Pancawati. Jurnal Ilmiah Manajemen Kesatuan, 8(2), 65-78. https://kuesioner.stiekesatuan.ac.id/index.php/jimkes/article/view/328.

Tjiptono, F. (2008). Strategi Pemasaran. Andi Offset.

Usmara, U. (2008). Pemikiran Kreatif Pemasaran. Amara Books.

Wahyuningsih, T., Yuesti, A., \& Sujana, I. W. (2021). The Influence of Service Quality, Relationship Marketing and Experiential Marketing on Loyalty with Satisfaction as Mediation in Royal Hotel Singosari Kuta. International Journal of Disaster Recovery and Business Continuity, 12(1), 16071628. http://pkkdhvci.com/journals/index.php/IJDRBC/article/view/36965.

Wahyuningtyas, F. M., Achmad, F., \& Zainul, A. (2017). The effect of experiential marketing on satisfaction and its impact on customer loyalty. Russian Journal of Agricultural and Socio-Economic Sciences, 61(1). https://cyberleninka.ru/article/n/16967538.

Widowati, R., \& Tsabita, F. (2017). The Influence of Experiential Marketing On Customer Loyaltythrough Customer Satisfaction as Intervening Variable. Jurnal Manajemen Bisnis, 8(2), 163-180. https://journal.umy.ac.id/index.php/mb/article/view/3945.

Wiedmann, K. P., Labenz, F., Haase, J., \& Hennigs, N. (2018). The power of experiential marketing: exploring the causal relationships among multisensory marketing, brand experience, customer perceived value and brand strength. Journal of Brand Management, 25(2), 101-118. https://doi.org/10.1057/s41262-017-0061-5.

Yuliawan, E., \& Ginting, M. (2016). Pengaruh experiential marketing terhadap kepuasan nasabah pada pt bank mandiri cabang medan balai kota. Jurnal Wira Ekonomi Mikroskil: JWEM, 6(1), 1-12. https://mikroskil.ac.id/ejurnal/index.php/jwem/article/view/253.

Yustica, D. D. (2021). The Effect of Experiential Marketing and Paylater Features on Customer Satisfaction and Repeat Interest. Eduvest-Journal of Universal Studies, 1(5), 263-279. https://eduvest.greenvest.co.id/index.php/edv/article/view/66. 